\title{
Characterizing the Subsurface Geology In and Around the U.S. Army Camp Stanley Storage Activity, South-Central Texas
}

The authors show how the U.S. Geological Survey acquired new downhole geophysical and petrophysical data and constructed a 3D EarthVision ${ }^{T M}$ model to better understand the geological controls on groundwater flow and (or) direction in and around the U.S. Army Camp Stanley Storage Activity (CSSA).

The geologic framework and hydrologic characteristics of aquifers are important components for understanding the Nation's subsurface geology and predicting its hydraulic budgets. Integrating surface lithostratigraphic and hydrostratigraphic mapping can help characterize the spatial distribution and hydraulic connectivity of an aquifer's permeable zones. Three-dimensional (3D) geologic modeling of an aquifer system can quantitatively characterize the connectedness of rock units across fault and fracture zones and enable geoscientists to visualize the spatial relations between the saturated and unsaturated stratigraphic units. Three-dimensional geologic framework model data can also be integrated into groundwater flow models, such as those constructed using MODFLOW (Christenson and others, 2011; Blome and Smith, 2012).

Several U.S. Geological Survey (USGS) projects, supported by the National Cooperative Geologic Mapping Program (NCGMP), have used multidisciplinary approaches over a 14-year period to reveal the surface and subsurface geologic frameworks of the Edwards and Trinity aquifers of central Texas and the Arbuckle-Simpson aquifer of south-central Oklahoma (fig. 1). Some of the project achievements include advancements in hydrostratigraphic mapping, 3D subsurface framework modeling, and airborne geophysical surveys as well as new methodologies that link geologic and groundwater flow models (Blome and others, 2007; Blome and Smith, 2012). One area where some of these milestones were achieved was in and around the U.S. Army Camp Stanley Storage Activity (CSSA), located in northwestern Bexar County, Texas, about 19 miles northwest of downtown San Antonio (fig. 1).

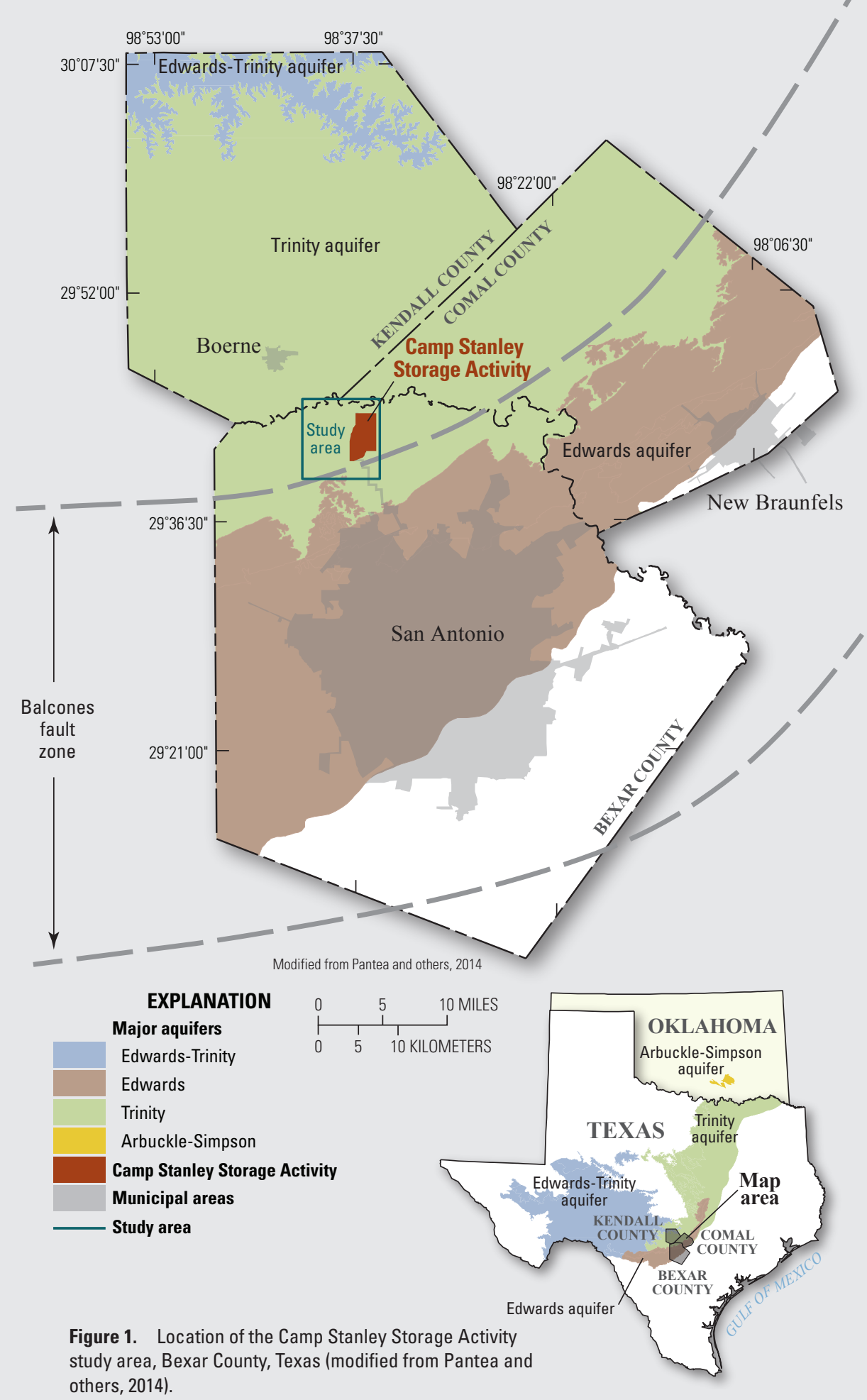




\section{Camp Stanley Storage Activity and Solvent Contamination}

Camp Stanley encompasses approximately 4,000 acres and borders Camp Bullis, a much larger military base to the east and southeast. Between 1906 and 1907, six tracts of land were purchased by the U.S. Government and designated the Leon Springs Military Reservation. In October 1917, the installation was designated Camp Stanley. In 1933, Camp Stanley was selected as an ammunition depot, and its current mission remains the receipt, storage, issuance, and maintenance of ordnance, in addition to quality assurance testing and maintenance of military weapons and ammunition (Pearson and Murphy, 2004; U.S. Environmental Protection Agency [EPA], 2015).

Extended military operations at Camp Stanley since the early 1900s have contaminated both the soils and groundwater in and off the base. Environmental investigations began at the CSSA in 1991 after the Texas Department of Health discovered elevated levels of the dissolved cleaning solvents tetrachloroethane (PCE), trichloroethane (TCE), and cis-1,2-dichloroethylene (cis-1,2-DCE) above the regulatory maximum contaminant levels. Other volatile organic compounds (VOCs) were discovered in a sample from a CSSA well located near the center of the CSSA. Follow-up studies confirmed that VOC contamination in nearby wells had even higher contaminant concentrations. One source of solvent contamination, known as Plume 1 (fig. 2), was identified as a former oxidation pond. Another area of solvent contamination, known as Plume 2 (fig. 2), is located in the southwestern corner of the base (U.S. Army, 2001; EPA, 2015). Starting in 1996, the first of 122 monitoring wells were installed (S.W. Pearson, Parsons, Austin, Texas, written commun., 2017). For more information, go to the CSSA website at https:// www.stanley.army.mil/.

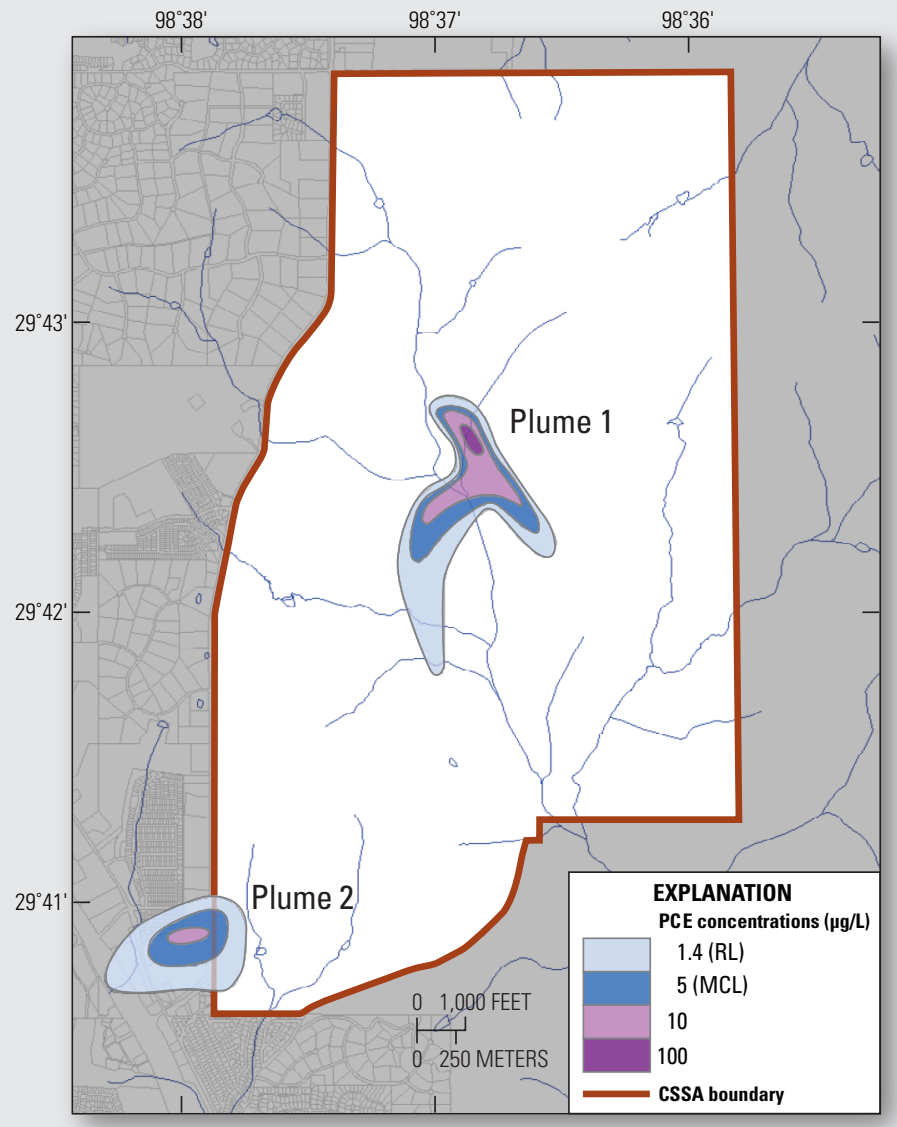

Parsons, 2017

Figure 2. Camp Stanley Storage Activity (CSSA) plume concentrations (used with permission by Parsons, Austin, Texas. PCE, tetrachloroethylene; $\mu \mathrm{g} / \mathrm{L}$, microgram per liter; $\mathrm{RL}$, reporting limit; $M C L$, maximum contaminant level).
The release of these solvents resulted in the contamination of the Middle Trinity aquifer, which is the primary water source for the military base and surrounding areas. The lower member of the Glen Rose Limestone, and Bexar Shale and Cow Creek Limestone Members of the Pearsall Formation, form the Middle Trinity aquifer (fig. 3). The lower member of the Glen Rose Limestone was initially subdivided into six informal hydrostratigraphic units, known as units A-F (fig. 3) by Blome and Clark (2014). These informal units were later named and described by Clark and Morris (2015) as the Bulverde, Little Blanco, Twin Sisters, Doeppenschmidt, Rust, and Honey Creek hydrostratigraphic units (fig. 3). Locally, the underlying Bexar Shale Member serves as the lower confining unit between the water-bearing Glen Rose Limestone and the Cow Creek Limestone Member of the Pearsall Formation (Pearson and Murphy, 2004).

Discussions with the CSSA Environmental Program Manager in 2009 led USGS personnel to coordinate several meetings with staff from the CSSA Environmental Office, the EPA, Parsons, and other CSSA cooperators. A number of topics were discussed at these meetings, and foremost among them was the need to better understand the local geology and the direction of contaminant flow both in the CSSA and residential areas south and west. Shortly thereafter, the USGS developed several Scope of Services Agreements (SOSAs) with the CSSA with the following objectives to be accomplished within a two-year period.

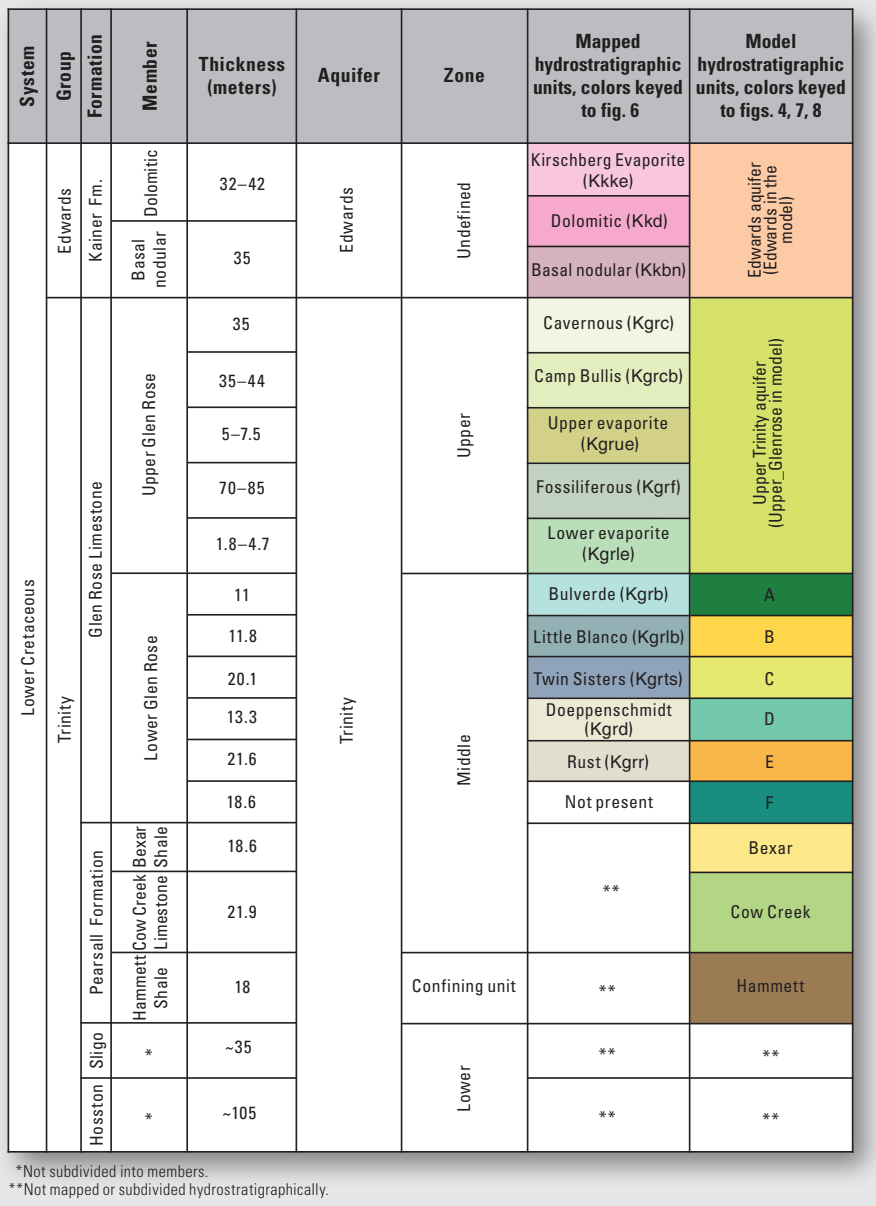

Figure 3. Lithostratigraphic and hydrostratigraphic correlation of mapped and modeled units in the Camp Stanley Storage Activity area (modified from Pantea and others, 2014). 
The first objective identified was the construction of a 3D geohydrologic framework model using the 3D software called EarthVision ${ }^{\mathrm{TM}}(\mathrm{EV})$. The interactive 3D model was built using surface hydrostratigraphic maps and subsurface borehole geophysical datasets of the base and areas west and south. A number of modifications were made to the SOSAs, which nearly doubled the size of the 3D model area. Included in the modifications was new field mapping to accurately locate all modeled faults and verify all well locations. The 3D EV model (fig. 4) was completed in 2013 and contains 11 hydrostratigraphic units (fig. 3) in descending stratigraphic order: 1 model layer representing the Edwards aquifer; 2 model layers representing the Upper Trinity aquifer; and 9 model layers representing the Middle Trinity aquifer. The top of the Hammett Shale Member (fig. 3) is the lowermost model unit and was used to propagate and validate fault structures and drill-hole data.

Figure 4. Camp Stanley Storage Activity three-dimensional EarthVision ${ }^{\mathrm{TM}}$ model showing model area, surface topology, subsurface model units, and fault structures (black near-vertical lines). Rocks of the Edwards aquifer (in pink) cap some of the hills in the southern part of the study area. View is from the east looking west (modified from Pantea and others, 2014).
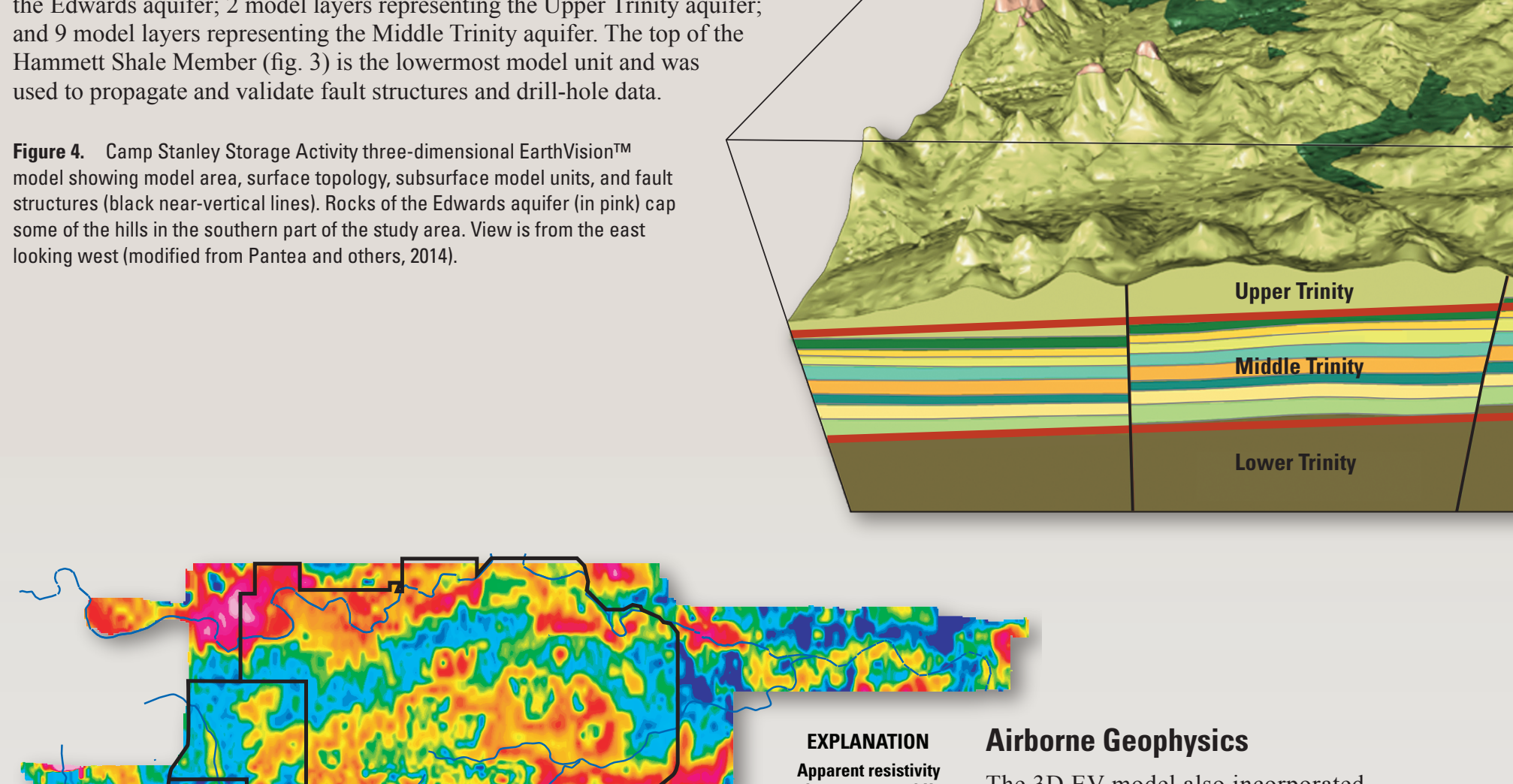

Apparent resistivity ohm meters $115 \mathrm{kHz}$

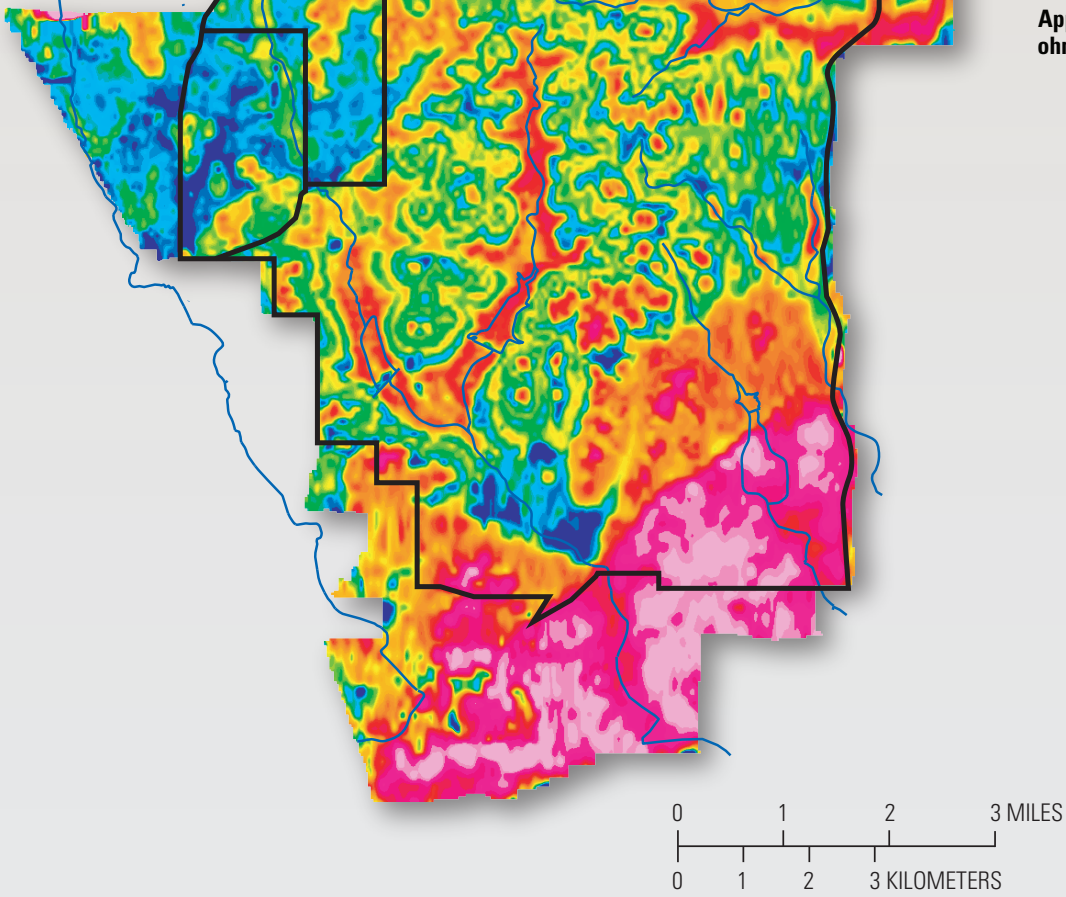

Figure 5. Helicopter electromagnetic survey of the Camp Stanley Storage Activity and adjacent Camp Bullis, located just north of San Antonio, Texas. The highest electromagnetic frequency of 115 kilohertz $(\mathrm{kHz})$ defines the geoelectric signatures of near surface strata (Smith and others, 2005).
The 3D EV model also incorporated geophysical data from the helicopter electromagnetic (HEM) survey of the CSSA and Camp Bullis (fig. 5) flown in December 2003 (Smith and others, 2005). The objective for flying the HEM survey was to study the subsurface electrical resistivity of aquiferbearing geologic features. This survey also refined the location of mapped faults and suggested that many more unmapped faults exist. The higher order colors (reds) indicate resistive lithologies, such as limestone, whereas the lower order colors (blues) denote mudstone and shale. Heavy, wavy blue lines represent the major drainages of the study area, and the black lines denote the boundaries of the military bases. At the highest electromagnetic (EM) frequency $(115 \mathrm{kHz})$, the exploration depth is only a few meters at most whereas the maximum exploration depth at the lowest frequency $(400 \mathrm{~Hz})$ is on the order of 100 meters. 


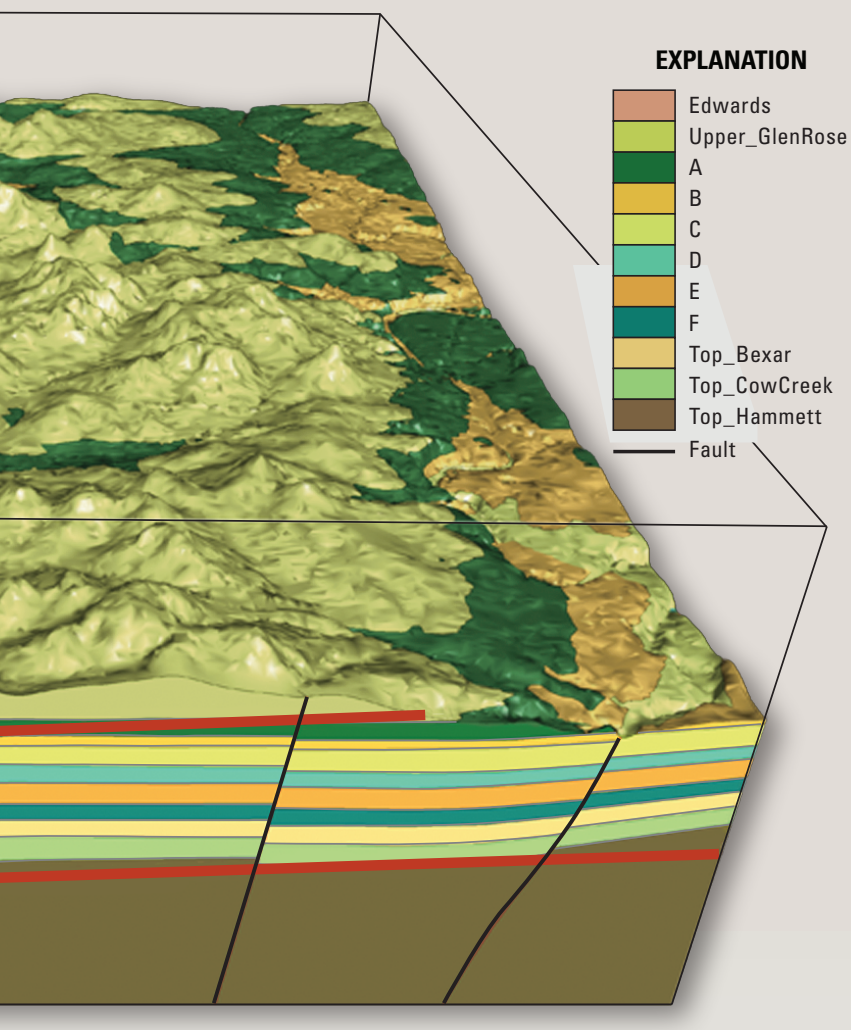

\section{Geologic Mapping}

The Lower Cretaceous geology of the CSSA area is characterized by alternating and intermixed sequences of shale, sandstone, carbonate, and evaporitic rocks assigned to the Trinity Group (Clark and others, 2016). The overlying Edwards Group contains carbonate, chert, and evaporitic rocks. The Trinity Group rocks were formed on a large, shallow marine carbonate platform (Commanche shelf), whereas Edwards Group rocks were formed in open marine to supratidal flat depositional environments.

The geologic map of northern Bexar County, Texas (Clark and others, 2009), was used to construct and constrain the CSSA 3D EV model (fig. 4). This map was later updated by Clark and others (2016) and describes and illustrates both the lithostratigraphy and hydrostratigraphy of the lower part of the Edwards aquifer down to the uppermost middle Trinity aquifer (fig. 6). Within the 3D EV model area, the lower part of the Edwards aquifer is present and includes the Dolomitic and Basal nodular hydrostratigraphic units. Rock outcrops associated with the Edwards aquifer cap only the hilltops south of the CSSA (fig. 6) and do not represent aquifer recharge areas within the 3D model area.

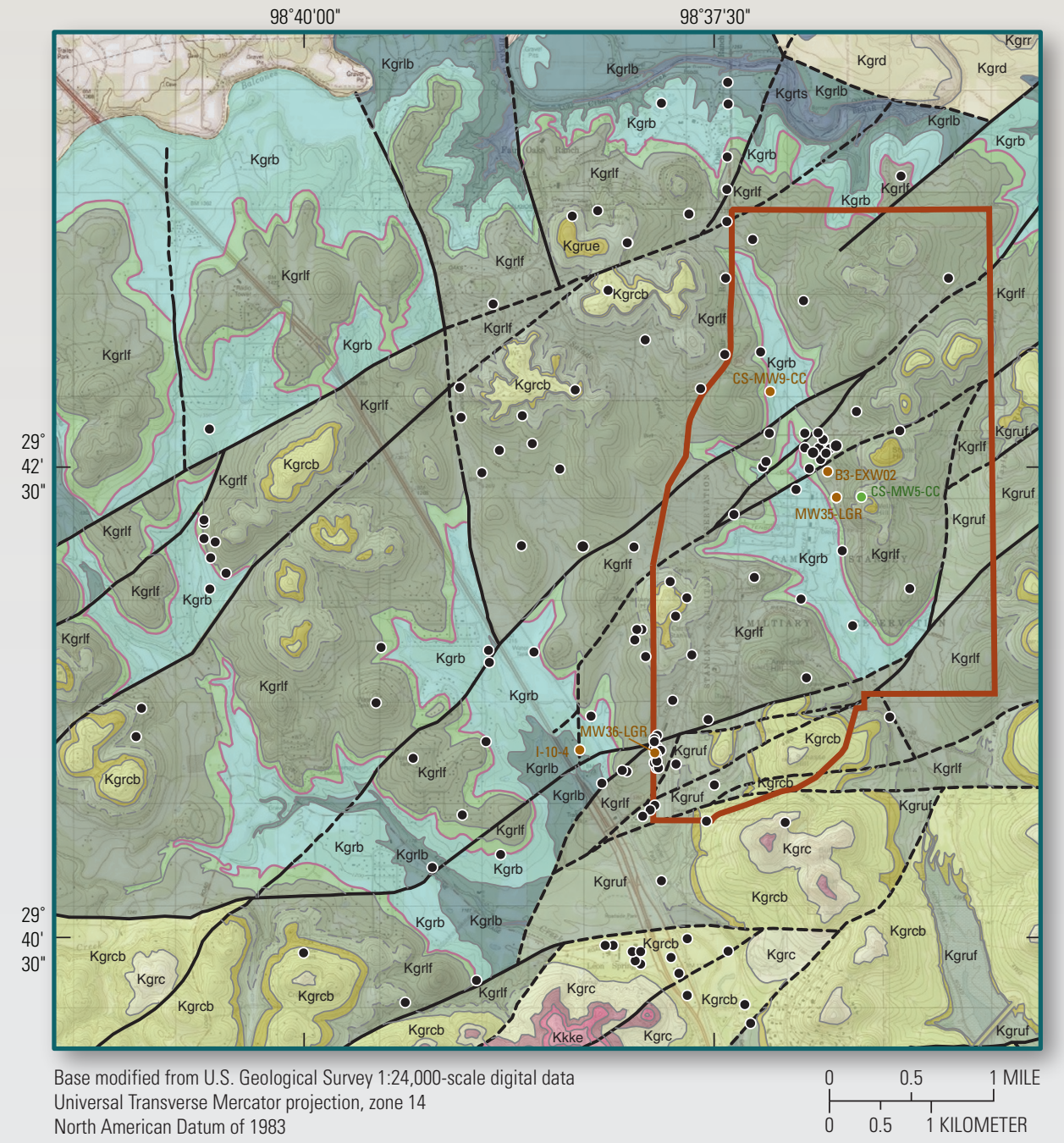

Figure 6. Geologic map of the Camp Stanley Storage Activity (CSSA) three-dimensional (3-D) model area (fig. 1) showing both lithostratigraphic and hydrostratigraphic units, mapped faults, and well locations (Clark and others, 2016). Red outline represents the CSSA boundary; blue-green outline represents the area encompassed by the CSSA 3-D EarthVision ${ }^{\mathrm{TM}}$ model of Pantea and others (2014).

\section{EXPLANATION}

\begin{tabular}{|c|c|c|c|}
\hline \multicolumn{2}{|c|}{$\begin{array}{c}\text { Hydrostratigraphic } \\
\text { member }\end{array}$} & & $\begin{array}{l}\text { Fault-Certain, } \\
\text { dashed where inferred }\end{array}$ \\
\hline \multicolumn{2}{|c|}{ Lower Cretaceous } & & Contact-Certail \\
\hline \multicolumn{2}{|c|}{ Edwards Group } & & dashed where inferred \\
\hline Iainer & rmation & & Corbula bed \\
\hline Kkke & Kirschberg Evaporite & & Camp Stanley \\
\hline Kkd & Dolomitic & & Model \\
\hline Kkbn & Basal nodular & & \\
\hline & Trinity Group & MW36-LGR & $\begin{array}{l}\text { Well with neutron log } \\
\text { and map identifier }\end{array}$ \\
\hline pper C & en Rose Limestone & CS-MW5-CC & Well sampled for Helium Gas \\
\hline Kgrc & Cavernous & & $\begin{array}{l}\text { Injection Analysis and } \\
\text { map identifier }\end{array}$ \\
\hline Kgrcb & Camp Bullis & & \\
\hline Kgrue & Upper evaporite & & \\
\hline Kgruf & Fossiliferous, upper & & \\
\hline Kgrlf & Fossiliferous, lower & & \\
\hline Kgrle & Lower evaporite & & \\
\hline
\end{tabular}

Lower Glen Rose Limestone

\begin{tabular}{|l|l}
\hline Kgrb & Bulverde \\
\cline { 1 - 2 } Kgrlb & Little Blanco \\
\hline Kgrts & Twin Sisters \\
\hline Kgrd & Doeppenschmidt \\
\cline { 1 - 1 } Kgrr & Rust \\
\hline
\end{tabular}
North American Datum of 1983 


\section{Objective 1. Construction of the 3-D EV Model of the CSSA and Areas North and West}

\section{Fault Structures}

Faults in northern Bexar County are part of the Miocene-age Balcones fault system historically called the Balcones fault zone (fig. 1). The southwest- to northeast-trending Balcones fault zone is an extensional system of normal en echelon faults that are downthrown to the southeast, and locally, high-angle normal faults are common. The CSSA 3D EV model (Pantea and others, 2014) revealed previously undetected horst and graben structures in the northeastern and southern parts of the study area. One graben was identified in the northeastern part of the study area and trends northeast to southwest (fig. 7). This graben structure may control or alter local groundwater flow as well as flow direction.

Figure 7. Horst and graben structures in the northeastern part of the Camp Stanley Storage Activity model area. View is from the northeast looking southwest (Pantea and others, 2014).

\section{EXPLANATION}

Edwards

Upper_GlenRose

A

B

C

D

E

Top_Bexar

Top_CowCree

Top_Hammett

Fault
In the CSSA model area, fault dips were interpreted to range from 52 to 75 degrees based on field mapping and drill-hole data (Clark, 2004). Although most fault displacements identified in the study area are 6 meters or less, a series of closely spaced faults near the southern boundary of the CSSA had greater displacements and one fault, located in the south-central part of the study area, exhibited up to 60 meters of displacement (fig. 8).

Figure 8. View of faulted top of the Hammett Shale hydrostratigraphic model unit with cross section showing all hydrostatigraphic units in the three-dimensional EarthVision ${ }^{\mathrm{TM}}$ model area (Pantea and others, 2014). View is towards the north; ( $\mathrm{m}$, meters).
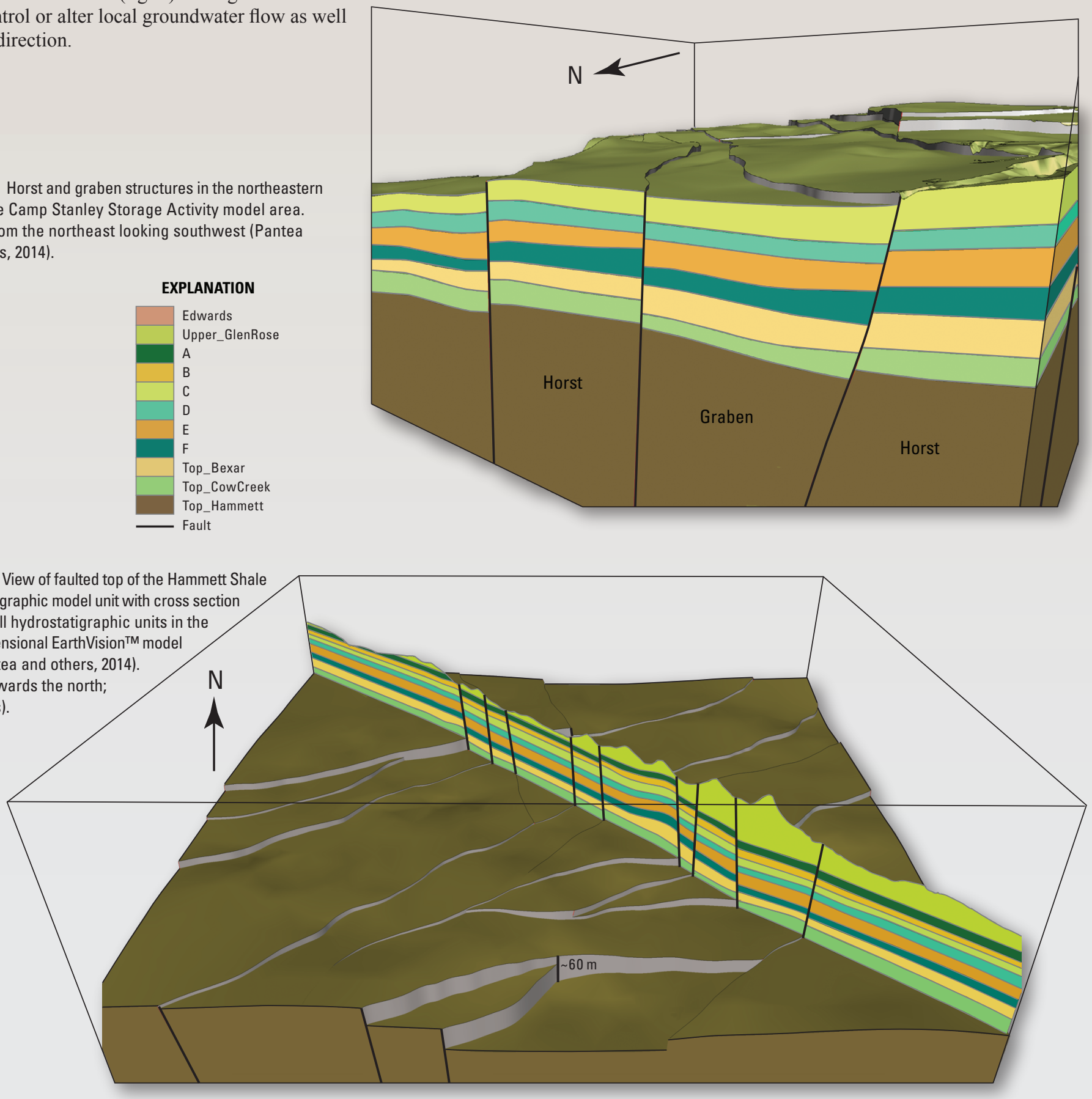


\section{Objective 2. Downhole Geophysical Logging}

The USGS analyzed and interpreted borehole geophysical data from 12 wells logged by the USGS during 2012 to supplement existing borehole data under Objective 2. The geophysical data included nine wells located on the military facility and three off base. Of particular note was the logging of two wells, MW9-CC and MW5-LGR, by the USGS to depths of more than 470 and 450 feet, respectively. Refer to Blome and Clark (2014) for details on the logging of these wells. Of the 12 wells, 4 were logged with a neutron geophysical tool to obtain effective porosity data. Neutron porosity measurements employ a neutron source to measure the hydrogen index in a reservoir, which is directly related to porosity in downhole formations. Borehole geophysical data collection included three mobilizations of logging equipment that were operated and maintained by the USGS (https://tx.usgs.gov/).

\section{Objective 3. Porosity and Permeability Measurements}

Two cores from wells MW9-CC and MW5-LGR were provided by the CSSA and shipped to the USGS Core Research Center (Denver, Colorado) for storage, slabbing, and preparation for petrophysical analysis. Lithologic character and type of observed porosity for all Glen Rose Limestone hydrostratigraphic units were described by Blome and Clark (2014) following the porosity classification of Choquette and Pray (1970) and the classification system of Dunham (1962).

Under Objective 3, 55 core plugs from well MW5-LGR, from intervals representing the lower member of the Glen Rose Limestone (fig. 3), were submitted to Weatherford Laboratories, Inc., (Golden, Colorado) for helium-gas-injection porosity and permeability analyses. Gas injection (also called gas expansion) is one of the accepted methods for measuring core or plug porosity and permeability and is preferred when analyzing poorly consolidated samples.

\section{References}

Blome, C.D., Faith, J.R., and Ozuna, G.B., 2007, Geohydrologic framework of the Edwards and Trinity aquifers, south-central Texas: U.S. Geological Survey Fact Sheet 2006-3145, 6 p., accessed January 17, 2017, at https://pubs.usgs.gov/fs/2006/3145/.

Blome, C.D., and Smith, D.V., 2012, Evolution of 3-D geologic framework modeling and its application to groundwater flow studies: U.S. Geological Survey Fact Sheet 2012-3106, 6 p., accessed January 24, 2017, at https://pubs.usgs.gov/fs/2012/3106/.

Blome, C.D., and Clark, A.K., 2014, Key subsurface data help to refine Trinity aquifer hydrostratigraphic units, south-central Texas: U.S. Geological Survey Data Series 768, 1 sheet, accessed March 3, 2017, at https://doi.org/10.3133/ds768.

Choquette, P.W., and Pray, L.C., 1970, Geologic nomenclature and classification of porosity in sedimentary carbonates: American Association of Petroleum Geologists, v. 54, no. 2, p. 207-250.

Christenson, Scott, Osborn, N.J., Neel, C.R., Faith, J.R., Blome, C.D., Puckette, James, and Pantea, M.P., 2011, Hydrology and simulation of groundwater flow in the Arbuckle-Simpson aquifer, south-central Oklahoma: U.S. Geological Survey Scientific Investigations Report 2011-5029, 104 p., accessed June 6, 2017, at https://pubs.usgs.gov/sir/2011/5029/.

Clark, A.K., 2004, Geologic framework and hydrogeologic characteristics of the Glen Rose Limestone, Camp Stanley Storage Activity, Bexar County, Texas: U.S. Geological Survey Scientific Investigations Map 2831, 1 sheet, scale 1:24,000, accessed April 19, 2017, at https://pubs.usgs.gov/sim/2005/2831

Clark, A.K., Golab, J.A., and Morris, R.R., 2016, Geologic framework and hydrostratigraphy of the Edwards and Trinity aquifers within northern Bexar and Comal Counties, Texas: U.S. Geological Survey Scientific Investigations Map 3366, 1 sheet, scale 1:24,000, pamphlet, 28 p., accessed May 3, 2017, at https://doi.org/10.3133/sim3366.

\section{Acknowledgments}

The authors would like to thank the following for their help and support on this project: the management and staff of the U.S. Army Camp Stanley Storage Activity Environmental Program and Parsons Corporation, Austin, Texas, for their help and support on this project. Special thanks goes to Scott Pearson (Parsons) and David V. Smith (USGS) for their helpful peer reviews, and to Diana Pedraza (USGS) for her help with the GIS and drafting of figures.

Porosity values (ambient, in porosity percent) for the lower member of the Glen Rose Limestone range from 6.0 percent to 30.2 percent, with a mean porosity value of 17.8 percent. Permeability values (to air, in millidarcys) were 0.0043 to 406 with a mean permeability of 14.7 (Blome and Clark, 2014). The helium injection porosity and permeability values and neutron geophysical $\log$ data will be used to construct future 3D property models for areas in and around the CSSA. Much of the funding for the CSSA 3D modeling and downhole geophysical and petrophysical data was through shared funding from the USGS National Cooperative Geologic Mapping Program and the CSSA Environmental Program.

Clark, A.R., Blome, C.D., and Faith, J.R., 2009, Map showing the geology and hydrostratigraphy of the Edwards aquifer catchment area, northern Bexar County, south-central Texas: U.S. Geological Survey Open-File Report 2009-1008, 24 p., 1 pl., scale 1:24,000, accessed August 11, 2017, at https://pubs.usgs.gov/of/2009/1008

Dunham, R.J., 1962, Classification of carbonate rocks according to depositional texture, in Ham, W.E., ed. Classification of Carbonate Rocks Symposium: American Association of Petroleum Geologists Memoir 1, p. 108-121, http://archives.datapages.com/data/specpubs/carbona2/data/a038/a038/0001/0100/0108.htm.

Pantea, M.P., Blome, C.D., and Clark, A.K., 2014, Three-dimensional model of the hydrostratigraphy and structure of the area in and around the U.S. Army-Camp Stanley Storage Activity Area, northern Bexar County, Texas: U.S. Geological Survey Scientific Investigations Report 2014-5074, 13 p., accessed February 15, 2017, at https://doi.org/10.3133/sir20145074.

Pearson, Scott, and Murphy, Brian, 2004, A case study of traditional and alternative monitoring techniques for solvent contamination within fractured bedrock: 2004 U.S. EPA/NGWA Fractured Rock Conference, State of the science and measuring success in remediation, Portland, Maine, p. 239-251, accessed April 3, 2017, at https://clu-in.org/products/siteprof/2004fracrockconf/cdr_pdfs/indexed/group1/239.pdf.

Smith, B.D., Cain, M.J., Clark, A.K., Moore, D.W., Faith, J.R., and Hill, P.L., 2005, Helicopter electromagnetic and magnetic survey data and maps, northern Bexar County, Texas: U.S. Geologic Survey Open-File Report 2005-1158, 119 p., accessed May 24, 2017, at https://pubs.usgs.gov/of/2005/1158/.

U.S. Army, 2001, Camp Stanley Storage Activity-Soil and groundwater contamination: U.S. Department of the Army Fact Sheet, no. 2, 2 p., accessed March 20, 2017, at http://www.stanley.army.mil/Volume1-6 FactSheets/02.pdf.

U.S. Environmental Protection Agency [EPA], 2015, Statement of basis, RVRA corrective action, Camp Stanley Storage Activity, Boerne, Texas: U.S. Environmental Protection Agency, accessed March 21, 2017, at https://www.epa.gov/tx/federal-facilities-texas.

By Charles D. Blome and Allan K. Clark

Prepared in cooperation with Camp Stanley Storage Activity and Parsons Corporation

Contacts:

Charles D. Blome

U.S. Geological Survey MS 980, Box 25046, DFC Denver, C0 80225 cblome@usgs.gov

\section{Allan K. Clark}

U.S. Geological Survey

5563 DeZavala Road, Suite 290

San Antonio, TX 78249

akclark@usgs.gov 